\title{
Jean-Pierre Tardieu. Resistencia de los negros en el Virreinato de México (siglos XVI- XVII). Madrid: Iberoamericana/Vervuert, 2017, 297 págs.
}

In this, his most recent of many books on the history of African slavery in Spanish America, Jean-Pierre Tardieu turns to the topic of slave resistance, specifically slave flight and armed rebellion in the Viceroyalty of Nueva España, as modern Mexico was known in the colonial period.

In this book, Tardieu carries us back to a new look at more overt forms of slave resistance during the early colonial period, when, as he points out, slaves quickly lost their exalted status as auxiliaries of Spanish expansionist efforts and became merchandise brought in insalubrious slave ships directly from the shores of Africa to the port of Veracruz to serve as compulsory labor in agriculture and mining. He traces the stories of two early, enslaved expeditionaries, Juan Garrido and Estabanico, esteemed participants in the battle at Tenochtitlán and the ill-fated Narváez expedition to Florida. These men, Tardieu sustains, adhered completely to the mentality of their masters, in a form of alienation that, he argues, was the result of "profound desire to resist the destructive force of their servile condition." (22) This notion of complicity with one's master as a form of resistance is not further developed in the book, but it might usefully be considered in the light of recent scholarly reconceptualization of resistance. Studies have argued for great slave agency, if not quite resistance, as they struggled for improved life conditions, and even their freedom in a variety of actions made possible by colonial institutions. Court actions, in particular, but also marriage, and even selfdenunciation to the Inquisition are now understood as ways that enslaved men and women sought to resist unbearable conditions. Tardieu's contention that the alienation experienced by displaced Africans often induced them to adopt their enslavers' mindset is certainly plausible, but it begs the question of the very definition, and limits, of what might reasonably be called resistance.

In the second section of the book, Tardieu returns to the more classic expressions of slave struggle to document the history of the armed cimarron communities established in the late sixteenth century by the creole slave, Yanga, and his followers in the harsh terrain beyond Veracruz. He gives an excellent description of the events that led to the capitulation of the fortified cimarron town of 60 houses and a church, a local that would later be called San Lorenzo, and he includes at the end of each chapter pertinent documents that allow

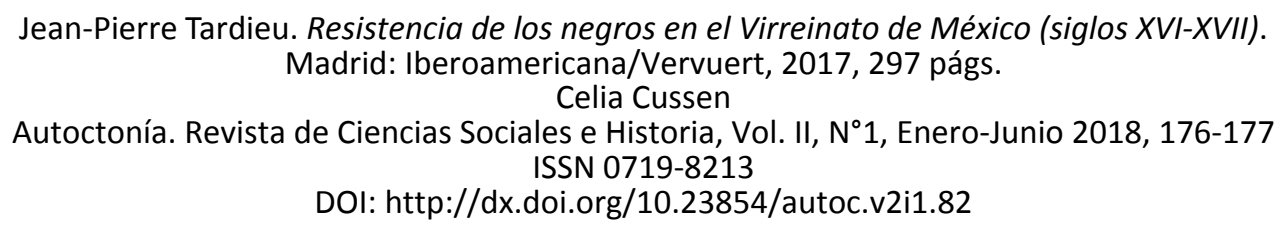

DOI: http://dx.doi.org/10.23854/autoc.v2i1.82 
the reader to reassess events and Tardieu's interpretation of them. It is indeed a fascinating, if well known story, and Tardieu's version is vivid and well informed. There are many perplexing details of the capitulation of the palenque and its subsequent life as a free town that make this an important episode for the purposes of comparison. The most biting of these telling details is the way the residents of the town were granted their freedom but also they were also obligated to hunt and capture enslaved men and women who followed in their path to freedom. In addition, at several points Tardieu joins the discussion of how fugitive slave groups may have adopted in their communities African forms of leadership and even, perhaps aspects of African belief systems.

In the final section, Tardieu turns to urban rebellions, particularly the "conjuración de negros" of 1612, a supposed plot for rebellion by blacks and mulattoes, enslaved and free, in the city of Nueva España, a revolt that was alleged to include the Indian population. The alleged conspirators, thirty-five men and women, were tortured until they confessed and then hanged in the city square. Measures were then taken to restrict the ability of slaves and free blacks to carry arms, circulate at night, and meet in groups, measures familiar to all of those who study the black population in any Spanish American colonial city at the time. Yet, what emerges quite clearly from Tardieu's analysis of events is, on one hand, a reminder of the importance of the religious congregations as spaces of limited autonomy for blacks, and sites of cultural survival. On the other hand, we are made aware once again of the constant tensions within Spanish society between a need for and even trust in enslaved men and women, and the fear of their insubordination, especially if it might involve inducing the Indian population to join a revolt. These tensions or, as Tardieu calls them, contradictions, lay at the heart of colonial Spanish slavery, of course, and are what, in the end, provided the opening for the many less overt forms of resistance mentioned above. The push and pull between a reliance on slavery and a deep-seated concern for the ability of a slave to be truly loyal to a master deeply tainted the life chances for Africans in the period described by Tardieu. It was also, of course, the driving force behind the escalating discrimination men and women of enslaved African descent in the Bourbon period and beyond. 